\title{
ПОРІВНЯЛЬНИЙ АНАЛІЗ СТАНУ РЕФОРМУВАННЯ СИСТЕМИ ОХОРОНИ ЗДОРОВ'Я В ПІЛОТНИХ РЕГІОНАХ УКРАЇНИ
}

\author{
ДУ “Український інститут стратегічних досліджень МОЗ України”, м. Київ
}

\begin{abstract}
Мета: проведення порівняльного аналізу впровадження нових організаційно-правових та фінансово-економічних механізмів у пілотних регіонах (Вінницька, Дніпропетровська області, м. Київ).

Матеріали і методи. Були використані статистичні дані пілотних регіонів; застосовані економічний, статистичний, методи порівняльного аналізу.

Результаты. У пілотних регіонах впроваджено нові підходи до організації роботи закладів охорони здоров'я та їх кадрового забезпечення: на базі існуючої мережі закладів створено структуровану за видами медичної допомоги систему медичного обслуговування; організовано роботу центрів первинної медичної допомоги; перепрофільовано заклади охорони здоров'я, що надають вторинну (спеціалізовану) медичну допомогу, з урахуванням інтенсивності її надання; створено центри екстреної медичної допомоги; оптимізовано кадрове забезпечення.

Висновки. Необхідно запровадити набутий у пілотних регіонах досвід реформування системи охорони здоров'я на національному рівні.
\end{abstract}

КЛЮЧОВІ СЛОВА: пілотні регіони, первинна медична допомога, екстрена медична допомога, вторинна медична допомога, ефективність, якість медичної допомоги.

Проведення реформи в охороні здоров'я було започатковане з прийняттям Закону України № 3612 від 7 липня 2011 року «Про порядок проведення реформування системи охорони здоров'я у Вінницькій, Дніпропетровській, Донецькій областях та місті Києві» [1]. Цей Закон визначає структурно-організаційні та правові засади реформування системи охорони здоров'я у зазначених регіонах, що дасть змогу:

- підвищити рівень медичного обслуговування населення, розширити можливості щодо його доступності та якості;

- впровадити нові підходи щодо організації роботи закладів охорони здоров'я в пілотних регіонах та їх фінансового забезпечення;

- підвищити ефективність використання бюджетних коштів, передбачених для фінансового забезпечення системи охорони здоров'я у пілотних регіонах.

Метою дослідження стало проведення порівняльного аналізу впровадження нових організаційно-правових та фінансово-економічних механізмів, спрямованих на підвищення ефективності та доступності медичного обслуговування населення і $є$ необхідними для розвитку системи охорони здоров'я України.

Матеріали і методи. При написанні статті використовувалися статистичні дані пілотних регіонів; застосовувалися наступні методи дослідження: економічний, статистичний, порівняльного аналізу.

(C) О.М. Дзюба, Н.Т. Кучеренко, Л.А. Карамзіна, 2015
Результати дослідження та їх обговорення. Міністерство охорони здоров'я України видало наказ № 494 від 11.06.2013 р. “Про удосконалення моніторингу реформи системи охорони здоров'я" [2], яким затвердило показники, що подають пілотні регіони для проведення оцінки стану реформування системи охорони здоров'я та за якими щорічно проводиться узагальнення інформації й аналіз стану реформування. У 2014 р. закінчено процеси розмежування первинного і вторинного рівнів надання медичної допомоги і створення Центрів первинної медико-санітарної допомоги (ЦПМСД) - всього $114^{1}$. У звітному році у м. Києві функціонує 28 ЦПМСД, з них у пілотних районах - 9, в інших - 19 (табл. 1).

У Дніпропетровській області більшість ЦПМСД створено у містах, у Вінницькій - у сільських районах, що пов'язано із адміністративно-територіальним устроєм цих областей та існуючими географічними особливостями розселення населення.

Особливістю створення та функціонування цПМСД у м. Києві є їх господарський статус у формі комунальних неприбуткових підприємств. У інших пілотних регіонах ЦПМСД створені і функціонують як бюджетні установи [4].

Кадровий потенціал для надання первинної медичної допомоги (ПМД) у пілотних регіонах мав наступні особливості.

У Дніпропетровській області ПМД надавалася 1537 лікарями, укомплектованість штатних посад лікарів фізичними особами становила $74,1 \%$.

\footnotetext{
${ }^{1}$ Дані представлені без Донецької області.
} 
Таблиця 1. Кількість Центрів первинної медико-санітарної допомоги у пілотних регіонах, 2014 p.

\begin{tabular}{|l|c|c|c|}
\hline \multicolumn{1}{|c|}{ Показник } & Дніпропетровська & Вінницька & м. Київ \\
\hline $\begin{array}{l}\text { Кількість створених ЦПМСД зі статусом } \\
\text { юридичної особи у містах, од. }\end{array}$ & 30 & 6 & 28 \\
\hline $\begin{array}{l}\text { Кількість створених ЦПМСД зі статусом } \\
\text { юридичної особи у сільських районах, од. }\end{array}$ & 23 & 27 & $\mathrm{x}$ \\
\hline $\begin{array}{l}\text { Всього ЦПМСД (міста/сільські райони) у } \\
\text { розрізі кожного пілотного регіону }\end{array}$ & 53 & 33 & 28 \\
\hline Всього ЦПМСД у пілотних регіонах & & \multicolumn{2}{|c|}{114} \\
\hline
\end{tabular}

у містах у ЦПМСД працювало 1134 лікаря, у сільських районах - 403, укомплектованість штатних посад лікарів фізичними особами у містах становить 77,0\%, у сільських районах - 66,8\%.

Чисельність лікарів загальної практики-сімейних лікарів становила 1226, у т.ч. у містах - 853, сільських районах - 373. Укомплектованість штатних посадлікарів загальної практики-сімейних лікарів (ЛЗП-СЛ) фізичними особами в області становить $76,0 \%$, у т.ч. у містах - 80,3\%, сільських районах $-67,8 \%$.

У Вінницькій області ПМД надавалася 953 лікарями, укомплектованість штатних посад лікарів фізичними особами становила 79,7\%. У містах у ЦПмСД працювало 573 лікарі, у сільських районах - 380, укомплектованість штатних посад лікарів фізичними особами у містах становить 89,0\%, у сільських районах - 69,0\%.

Чисельність лікарів загальної практики-сімейних лікарів становила 832, у т.ч. у містах - 470, у сільських районах - 362. Укомплектованість штатних посад ЛЗП-СЛ фізичними особами в області становить 79,4\%, у т.ч. у містах - 90,0\%, у сільських районах - 68,9\%.

У м. Києві ПМД надавалася 1546 лікарями, укомплектованість штатних посад лікарів фізичними особами становить 73,1\%.

Чисельність ЛЗП-СЛ становила 667, укомплектованість штатних посад фізичними особами $74,8 \%$ (табл. 2).

Рівень укомплектованості штатних посад лікарів фізичними особами найнижчий у м. Києві (73,1\%), найвищий - у Вінницькій області $(79,7 \%)$. Лікарів загальної практики-сімейних лікарів найнижчий у м. Києві $(74,8 \%)$, найвищий у Вінницькій області $(79,4 \%)$.

Аналіз отриманих даних з реформування ПМД у пілотних областях засвідчив, що намітилися певні позитивні зрушення щодо кадрового забезпечення:

- у Дніпропетровській області чисельність ЛЗП-СЛ зросла з 1068 у 2013 р. до 1226 у 2014 р., відповідно на 10 тис. населення з 3,2 у 2013 р. до 3,7 у 2014 р.;

Таблиця 2. Дані про лікарські кадри, які надавали первинну медичну допомогу у Центрах первинної медико-санітарної допомоги

\begin{tabular}{|c|c|c|c|c|c|c|c|c|}
\hline \multirow[t]{2}{*}{ Показник } & 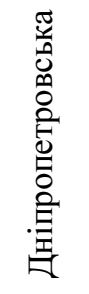 & 营 & $\begin{array}{l}: \because \\
:=1 \\
\dot{\Sigma} \\
\dot{\Sigma}\end{array}$ & 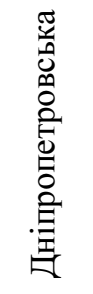 & 莺 & 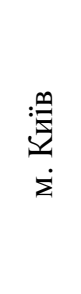 & 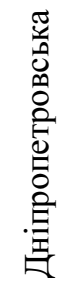 & 营 \\
\hline & \multicolumn{3}{|c|}{ всього } & \multicolumn{3}{|c|}{ у містах } & \multicolumn{2}{|c|}{$\begin{array}{l}\text { у сільських } \\
\text { районах }\end{array}$} \\
\hline $\begin{array}{l}\text { Кількість фізичних осіб лікарів, } \\
\text { що надають ПМД, осіб }\end{array}$ & 1537 & 953 & 1546 & 1134 & 573 & 1546 & 403 & 380 \\
\hline $\begin{array}{l}\text { Кількість фізичних осіб } \\
\text { ЛЗП-СЛ }\end{array}$ & 1226 & 832 & 667 & 853 & 470 & 667 & 373 & 362 \\
\hline $\begin{array}{l}\text { Укомплектованість штатних } \\
\text { посад лікарів, які надають } \\
\text { ПМСД, фізичними особами - } \\
\text { лікарями, відсотків }\end{array}$ & 74,1 & 79,7 & 73,1 & 77,1 & 89,0 & 73,1 & 66,8 & 69,0 \\
\hline $\begin{array}{l}\text { Укомплектованість штатних } \\
\text { посад ЛЗП-СЛ фізичними } \\
\text { особами - ЛЗП-СЛ }\end{array}$ & 76,0 & $\begin{array}{l}79,4 \\
\end{array}$ & 74,8 & 80,3 & 90,0 & 74,8 & 67,8 & 68,90 \\
\hline
\end{tabular}


- у Вінницькій області чисельність ЛЗП-СЛ зросла з 750 у 2013 р. до 832 у 2014 р., відповідно на 10 тис. населення з 4,63 у 2013 р. до 5,2 у 2014 р.;

- ум. Києві чисельність ЛЗП-СЛ зросла з 503 у 2013 р. до 667 у 2014 р., відповідно на 10 тис. населення з 1,8 у 2013 р. до 2,3 у 2014 р.

У Дніпропетровській області ПМД надавалася ЛЗП-СЛ, їх питома вага у загальній кількості лікарів, які займаються лікувальною справою, становила $79,8 \%$, у Вінницькій - 84,7\%, у м. Києві - 43,2\%.

Первинна медична допомога у Дніпропетровській області надавалася ЛЗП-Сл 79,8\% населення; у Вінницькій - 93,0\%, у м. Києві - 51,9\% населення, тобто рівень охоплення цим видом медичної допомоги найвищий у Вінницькій області, найнижчий - у м. Києві.

Аналіз рівня навантаження на лікарів, які надавали ПМД, засвідчив, що у всіх пілотних регіонах фактичне навантаження в розрахунку на одного лікаря (фізичну особу) перевищувало нормативні показники, як у містах, так і у сільських районах, особливо це стосувалося дільничних терапевтів (особливо в містах Дніпропетровської області - відповідно 3682). Найнижчі рівні навантаження на дільничних педіатрів спостерігалися у містах та сільських районах Вінницької області - відповідно 853 та 704 осіб (табл. 3).

\section{Таблиця 3. Дані про навантаження на лікарів, які надавали} первинну медичну допомогу

\begin{tabular}{|l|c|c|c|c|c|}
\hline \multirow{2}{*}{ Показник } & \multicolumn{2}{|c|}{ Дніпропетровська } & \multicolumn{2}{|c|}{ Вінницька } & м. Київ \\
\cline { 2 - 6 } & у містах & $\begin{array}{c}\text { у сільських } \\
\text { районах }\end{array}$ & у містах & $\begin{array}{c}\text { у сільських } \\
\text { районах }\end{array}$ & всього \\
\hline $\begin{array}{l}\text { Середня кількість прикріпленого } \\
\text { населення на одну фізичну особу } \\
\text { ЛЗП-СЛ }\end{array}$ & 2050 & 2133 & 1562 & 2183 & 2504 \\
\hline $\begin{array}{l}\text { Середня кількість прикріпленого } \\
\text { населення на одну фізичну особу } \\
\text { дільничного терапевта }\end{array}$ & 3682 & 2315 & 1708 & 1808 & 2567 \\
\hline $\begin{array}{l}\text { Середня кількість прикріпленого } \\
\text { населення на одну фізичну особу } \\
\text { дільничного педіатра }\end{array}$ & 1217 & 1207 & 853 & 704 & 1063 \\
\hline
\end{tabular}

Рівень навантаження на одного ЛЗП-СЛ становив:

- у Дніпропетровській області - 2050 осіб у містах, у сільських районах - 2133 осіб;

- у Вінницькій області - 1562 особи у містах; у сільських районах - 2183 осіб;

- у м. Києві - 2504 осіб.

Щодо забезпеченості первинної ланки молодшими медичними працівниками, то найбільшу чисельність фізичних осіб молодших медичних працівників з медичною освітою, які надавали ПМД, зафіксовано у Дніпропетровській області (3051 особа).

Найвищі показники укомплектованості фізичними особами штатних посад молодших медичних працівників з медичною освітою, які надають ПМД, були у Вінницькій $(95,5 \%)$, найнижчі у м. Києві $(68,3 \%)$ та Дніпропетровській області (81,6\%) (табл. 4).

Рівні укомплектованість молодшими медичними працівниками з медичною освітою, які надають ПМД, штатних посад найвищі у Дніпропетровській та Вінницькій областях (92,7\% і 93,6\% відповідно), у м. Києві на рівні 82,7\%. За даними моніторингу, величина показника у містах та сільських районах Дніпропетровської та Вінницької областей практично однакова.

Співвідношення штатних посад лікарів ПМСД до штатних посад молодших працівників з медичною освітою у закладах ПМСД найвище у Вінницькій області (1:2,6), у Дніпропетровський на рівні 1:1,6, у м. Києві 1:0,66.

У Вінницькій області найвищий показник молодших медичних працівників з медичною освітою, які самостійно працювали у структурних підрозділах сільської місцевості, - 1074 особи, а у Дніпропетровській області - 395 (табл. 5).

У сільських районах оснащення ЦПМСД комп'ютерами становить у Вінницькій області 98,0\%, у Дніпропетровській - 54,4\%. Оснащення транспортними засобами у м. Києві та Дніпропетровській обл. становить 100\%, у Вінницький 56,5\%. Найвищий показник оснащення закладів комп'ютерами у містах Вінницької області (100\%), найнижчий - у м. Києві (38,8\%) (табл. 6).

Щодо доступності лікарських засобів для сільського населення, у звітному році у Дніпропетровській і Вінницькій областях збільшено мережу пунктів реалізації лікарських засобів (Дніпропетровська - 93,1\%, Вінницька - 62,0\% від їх загальної чисельності) (табл. 7). 
Таблиця 4. Дані щодо забезпеченості первинної ланки молодшими медичними працівниками з медичною освітою

\begin{tabular}{|c|c|c|c|c|c|c|c|}
\hline \multirow[b]{2}{*}{ Показник } & \multicolumn{3}{|c|}{ Дніпропетровська } & \multicolumn{3}{|c|}{ Вінницька } & \multirow{2}{*}{$\begin{array}{l}\text { м. Київ } \\
\text { всього }\end{array}$} \\
\hline & всього & у містах & $\begin{array}{c}\text { у } \\
\text { сільських } \\
\text { районах }\end{array}$ & всього & у містах & $\begin{array}{c}\text { у } \\
\text { сільських } \\
\text { районах }\end{array}$ & \\
\hline $\begin{array}{l}\text { Кількість штатних посад } \\
\text { молодших медичних працівників } 3 \\
\text { медичною освітою, які надають } \\
\text { ПМД }\end{array}$ & 3740 & 2265,5 & 1474,5 & 3089,5 & 1086,75 & 2002,75 & 2989,0 \\
\hline $\begin{array}{l}\text { Кількість зайнятих посад } \\
\text { молодших медичних працівників } 3 \\
\text { медичною освітою, які надають } \\
\text { ПМД }\end{array}$ & 3468,5 & 2126,75 & 1341,75 & 2890,25 & 1025,5 & 1864,75 & 2469,25 \\
\hline $\begin{array}{l}\text { Кількість фізичних осіб молодших } \\
\text { медичних працівників з медичною } \\
\text { освітою, які надають ПМД }\end{array}$ & 3051 & 1745 & 1306 & 2950 & 1012 & 1938 & 2041 \\
\hline $\begin{array}{l}\text { Укомлектованість фізичними } \\
\text { особами молодших медичних } \\
\text { працівників з медичною освітою, } \\
\text { які надають ПМД, штатних посад } \\
\text { молодших медичних працівників } 3 \\
\text { медичною освітою, які надають } \\
\text { ПМД }\end{array}$ & 81,6 & 77,0 & 88,6 & 95,5 & 93,1 & 96,8 & 68,3 \\
\hline $\begin{array}{l}\text { Укомплектованість зайнятими } \\
\text { посадами молодших медичних } \\
\text { працівників з медичною освітою, } \\
\text { які надають ПМД, штатних посад } \\
\text { молодших медичних працівників } 3 \\
\text { медичною освітою, які надають } \\
\text { ПМД }\end{array}$ & 92,7 & 93,9 & 91,0 & 93,6 & 94,4 & 93,1 & 82,7 \\
\hline
\end{tabular}

Таблиця 5. Дані про навантаження на лікарів, які надавали првинну медичну допомогу

\begin{tabular}{|l|c|c|}
\hline \multicolumn{1}{|c|}{ Показник } & Дніпропетровська & Вінницька \\
\hline $\begin{array}{l}\text { Кількість фізичних осіб, які працюють з лікарями у } \\
\text { сільській місцевості }\end{array}$ & 911 & 1938 \\
\hline $\begin{array}{l}\text { Кількість фізичних осіб, які працюють у структурних } \\
\text { підрозділах на первинному рівні самостійно у сільській } \\
\text { місцевості }\end{array}$ & 395 & 1074 \\
\hline
\end{tabular}

Таблиця 6. Дані щодо оснащення Центрів первинної медико-санітарної допомоги

\begin{tabular}{|c|c|c|c|}
\hline Показник & Дніпропетровська & Вінницька & м. Київ \\
\hline \multicolumn{4}{|l|}{ У сільських районах: } \\
\hline транспортними засобами & 100 & 60,7 & \multirow{3}{*}{$\mathrm{x}$} \\
\hline засобами зв'язку & 100 & 100 & \\
\hline комп’ютерами & 54,4 & 98,0 & \\
\hline \multicolumn{4}{|l|}{$y_{\text {мicmax: }}$} \\
\hline транспортними засобами & 100 & 56,5 & 100 \\
\hline засобами зв'язку & 100 & 100 & 100 \\
\hline комп'ютерами & 99,4 & 100 & 38,8 \\
\hline
\end{tabular}


Таблиця 7. Дані щодо доступності лікарських засобів для сільського населення

\begin{tabular}{|c|c|c|}
\hline Показник & Дніпропетровська & Вінницька \\
\hline $\begin{array}{l}\text { Кількість сільських лікарських амбулаторій і ФАПів, які } \\
\text { мають пункти реалізації лікарських засобів, абс. число }\end{array}$ & 639 & 742 \\
\hline $\begin{array}{l}\text { Загальна кількість сільських лікарських амбулаторій і } \\
\text { ФАПів, абс. число }\end{array}$ & 595 & 1199 \\
\hline $\begin{array}{l}\text { Питома вага сільських лікарських амбулаторій і ФАПів, які } \\
\text { мають пункти реалізації лікарських засобів, у загальній } \\
\text { кількості лікарських амбулаторій і ФАПів, у відсотках }\end{array}$ & 93,1 & 62,0 \\
\hline
\end{tabular}

За даними моніторингу, у 2014 р. квартири було виділено у всіх пілотних регіонах, за винятком міст Вінницької області та м. Києва (табл. 8).

Найвищі рівні видатків на надання ПМД у розрахунку на одного жителя зафіксовано у м. Києві (250,3 грн), найнижчі - у Вінницькій області (229,77 грн). На ПМД від зведеного бюджету (загальний бюджет та спеціальний фонд) у Вінницькій області спрямовано 22,1\% видатків, у м. Києві - 18,6\% (табл. 9).

Затверджено Плани-схеми госпітальних округів (у Дніпропетровській області планується створення 12 ГО, у Вінницькій та м. Київ - по 3) та плани перспективного розвитку закладів охорони здоров'я [3].

У пілотних регіонах у звітному році продовжувалася робота щодо оптимізації ліжкового фонду. у всіх пілотних регіонах забезпеченість ліжками на 10 тис. населення становила: у Вінницькій області - 40,0; Дніпропетровській області та м. Києві - 62,54 та 62,9 відповідно.
У Вінницькій області 64,5\% оперативних втручань від загальної кількості оперативних втручань проведено в амбулаторно-поліклінічних умовах (включаючи “хірургію одного дня"), у м. Києві 46,5\%, Дніпропетровській області - 43,9\%.

Найвищий рівень летальності та післяопераційної летальності реєструється у м. Києві (відповідно 1,67 та 0,87), найнижчий - у Вінницькій області (відповідно 0,9 та 0,3) (табл. 10).

Центри екстреної медичної допомоги та медицини катастроф функціонували у всіх пілотних регіонах та у м. Києві [5]. Тривало створення оперативно-диспетчерської служби у Дніпропетровській та Вінницькій областях. У м. Києві створена Єдина оперативно-диспетчерська служба (перша черга), проводилася робота над впровадженням другої черги Національного проекту "Вчасна допомога" - підключення до Єдиної оперативно-диспетчерської служби міста Києва на базі Центру екстреної медичної допомоги та медицини катастроф міста Києва.

Таблиця 8. Дані щодо забезпечення медичних працівників первинної ланки житлом

\begin{tabular}{|l|c|c|c|c|c|}
\hline \multicolumn{1}{|c|}{ Показник } & \multicolumn{2}{|c|}{ Дніпропетровська } & \multicolumn{2}{|c|}{ Вінницька } & \multirow{2}{*}{ м. Київ } \\
\cline { 2 - 5 } & $\begin{array}{l}\text { сільські } \\
\text { райони }\end{array}$ & міста & $\begin{array}{c}\text { сільські } \\
\text { райони }\end{array}$ & міста \\
\hline $\begin{array}{l}\text { Кількість лікарів ПМСД, не забезпечених } \\
\text { житлом, всього }\end{array}$ & 22 & 31 & 35 & 10 & 141 \\
\hline $\begin{array}{l}\text { Кількість молодших медичних працівників } \\
\text { медичною освітою у закладах ПМСд, не } \\
\text { забезпечених житлом, всього }\end{array}$ & 27 & 22 & 79 & 28 & 94 \\
\hline $\begin{array}{l}\text { Кількість виділених квартир для вказаної } \\
\text { категорії, од. }\end{array}$ & 7 & 5 & 6 & 0 & 0 \\
\hline
\end{tabular}

Таблиця 9. Видатки на надання первинної медичної допомоги

\begin{tabular}{|l|c|c|c|}
\hline \multicolumn{1}{|c|}{ Показник } & Дніпропетровська & Вінницька & м. Київ \\
\hline $\begin{array}{l}\text { Видатки на надання ПМД у розрахунку на одного } \\
\text { жителя, грн }\end{array}$ & 244,3 & 229,77 & 18,3 \\
\hline $\begin{array}{l}\text { Відсоток витрат на ПМД від зведеного бюджету } \\
\text { загальний бюджет та спеціальний фонд) }\end{array}$ & 19,5 & 22,1 & 20,5 \\
\hline $\begin{array}{l}\text { Відсоток витрат на ПМД загального фонду зведеного } \\
\text { бюджету }\end{array}$ & 20,1 & 21,4 & 7,9 \\
\hline $\begin{array}{l}\text { Відсоток витрат на ПМД спеціального фонду } \\
\text { зведеного бюджету }\end{array}$ & 9,7 & 28,9 & \\
\hline
\end{tabular}


Таблиця 10. Окремі показники, які характеризують надання вторинної (спеціалізованої) медичної допомоги

\begin{tabular}{|c|c|c|c|}
\hline Показник & Дніпропетровська & Вінницька & м. Київ \\
\hline Загальна чисельність ліжок, од. & 20571 & 6444 & 18114 \\
\hline Забезпеченість ліжками на 10 тис. населення & 62,5 & 40,0 & 62,9 \\
\hline Рівень госпіталізації на 100 жителів, всього & 19,2 & 15,3 & 17,8 \\
\hline Рівень госпіталізації дитячого населення на 100 дітей & 18,6 & 13,1 & 13,5 \\
\hline Летальність всього по області & 1,49 & 0,9 & 1,67 \\
\hline Добова летальність & 0,37 & 0,3 & 18,6 \\
\hline Післяопераційна летальність & 0,65 & 0,3 & 0,87 \\
\hline $\begin{array}{l}\text { Кількість оперативних втручань, проведених в } \\
\text { амбулаторно-поліклінічних умовах (включаючи } \\
\text { “ххірургію одного дня”), на } 10 \text { тис. населення }\end{array}$ & 352,9 & 508,3 & 486,5 \\
\hline $\begin{array}{l}\text { Питома вага оперативних втручань, проведених в } \\
\text { амбулаторно-поліклінічних умовах (включаючи } \\
\text { “хірургію одного дня”), у загальній кількості } \\
\text { оперативних втручань }\end{array}$ & 43,90 & 64,5 & 46,5 \\
\hline
\end{tabular}

У Дніпропетровській області створено 81 пункт постійного/тимчасового базування (план виконання 100\%), у Вінницькій - 40 пунктів (план виконання 100\%), у м. Києві - 29 пунктів (план виконання 100\%).

У Дніпропетровській області забезпеченість населення бригадами екстреної (швидкої) медичної допомоги (ЕМД (ШМД)) становила 0,84; у Вінницькій - 0,74; у м. Києві - 0,46 бригади на 10 тис. населення.

У Дніпропетровській та Вінницькій областях медична допомога надавалася фельдшерськими бригадами ЕМД, частка яких у їх загальній чисельності становила $65,7 \%$ та $54,5 \%$ відповідно. У м. Києві така допомога надавалася переважно лікарськими бригадами, частка яких становила 83,9\% (табл. 11).

Таблиця 11. Характеристика типів та структури бригад екстреної (швидкої) медичної допомоги, 2014 р.

\begin{tabular}{|l|c|c|c|}
\hline \multicolumn{1}{|c|}{ Показник } & Дніпропетровська & Вінницька & м. Київ \\
\hline Кількість існуючих бригад ШМД всього, у т.ч.: & 277 & 119,5 & 155,5 \\
\hline фельдшерських & 182 & 71,5 & 32 \\
\hline лікарських & 95 & 39 & 130,5 \\
\hline спеціалізованих & 17 & 9 & 7 \\
\hline $\begin{array}{l}\text { Питома вага фельдшерських бригад ШМД у їх } \\
\text { загальній кількості, у відсотках }\end{array}$ & 65,7 & 54,5 & 20,6 \\
\hline $\begin{array}{l}\text { Питома вага лікарських бригад ШМД у їх загальній } \\
\text { кількості, у відсотках }\end{array}$ & 34,2 & 32,6 & 83,9 \\
\hline $\begin{array}{l}\text { Питома вага спеціалізованих бригад ШМД у їх } \\
\text { загальній кількості, у відсотках }\end{array}$ & 6,1 & 7,5 & 4,5 \\
\hline
\end{tabular}

У закладах охорони здоров'я, що надавали ЕМД населенню пілотних регіонів, укомплектованість штатних посад лікарів фізичними особами найвища у Вінницькій області $(77,35 \%)$, найнижча - у Дніпропетровській $(55,1 \%)$; штатних посад лікарів зайнятими найвища у м. Києві (100\%), найнижча - у Дніпропетровській області $(81,0)$. За рівнем укомплектованості штатних посад молодших медичних працівників з медичною освітою фізичними особами лідирують Вінницька область $(97,6 \%)$ та м. Київ $(89,0 \%)$ (табл. 12).
Забезпечувалося виконання заходів щодо своєчасності надання ШМД:

- у Дніпропетровській області 90,2\% викликів ШМД у сільській місцевості здійснено з доїздом до пацієнта до 20 хвилин; у містах 91,3\% викликів забезпечено з доїздом до пацієнта у 10-хвилинний термін;

- у Вінницькій області 86,9\% викликів ШМД у сільській місцевості здійснено з доїздом до пацієнта до 20 хвилин; у містах 93,5\% викликів забезпечено з доїздом до пацієнта у 10-хвилинний термін; 
- у м. Києві 86,1\% екстрених викликів ШМД забезпечено з доїздом до пацієнта у 10-хвилинний термін.

Кількість викликів ЕМД (ШМД) становила у Дніпропетровській області 260 на 1000 населення; у м. Києві - 175,7 на 1000 населення.

Дані щодо виїздів бригад ЕМД, які закінчились летально, наведено у табл. 13.

Найкраще забезпечені навігаційним та радіозв'язком автомобілі ЕМД у м. Києві (100\%), найгірше - у Вінницькій області (22,0\%) (табл. 14).

Показники чисельності населення, яке в середньому обслуговує один лікар, що надає ПМД (дільничний терапевт, дільничний педіатр, ЛЗП-СЛ), у Дніпропетровській області становили 2072 особи, у м. Києві - 2009, найнижчі у Вінницькій області (1785).

Питома вага хворих із занедбаними формами злоякісних новоутворень серед усіх хворих з візуальними формами злоякісного новоутворення, взятих на облік у звітному році з вперше встановленим діагнозом, у Дніпропетровській області становила 17,1\%, у м. Києві - 12,9\%, у Вінницькій області - 5,3\%.

Питома вага хворих на занедбані форми (фіброзно-кавернозний) туберкульозу серед усіх форм туберкульозу легень у Дніпропетровській, Вінницькій області та м. Києві становили 1,1\%, 0,5\% та 0,18\% відповідно.

Показник проведених оперативних втручань у стаціонарах на 10 тис. населення у Дніпропетровській області - 593,2; Вінницькій - 564,3; м. Києві - 560,1.

Кількість проведених оперативних втручань в стаціонарах при наданні термінової хірургічної допомоги на 10 тис. населення становила у м. Києві 38,0; Дніпропетровській області - 30,2; Вінницькій - 27,9 (табл. 15).

Таблиця 12. Дані щодо кадрового забезпечення надання екстреної медичної допомоги, 2014 р.

\begin{tabular}{|l|c|c|c|}
\hline \multicolumn{1}{|c|}{ Показник } & Дніпропетровська & Вінницька & м. Київ \\
\hline Кількість фізичних осіб лікарів & 391 & 257 & 393 \\
\hline $\begin{array}{l}\text { Укомплектованість штатних посад фізичними особами } \\
\text { лікарями }\end{array}$ & 55,1 & 77,35 & 60,4 \\
\hline $\begin{array}{l}\text { Укомплектованість зайнятими посадами лікарів штатних } \\
\text { посад }\end{array}$ & 81,0 & 86,2 & 100 \\
\hline $\begin{array}{l}\text { Кількість фізичних осіб молодших медичних працівників } \\
\text { з медичною освітою, всього }\end{array}$ & 1604 & 832 & 1267 \\
\hline $\begin{array}{l}\text { Укомплектованість штатних посад молодших медичних } \\
\text { працівників з медичною освітою фізичними особами }\end{array}$ & 87,2 & 97,6 & 89,0 \\
\hline $\begin{array}{l}\text { Укомплектованість штатних посад молодших медичних } \\
\text { працівників з медичною освітою зайнятими }\end{array}$ & 91,5 & 98,2 & 100 \\
\hline
\end{tabular}

Таблиця 13. Дані щодо виїздів бригад екстреної (швидкої) медичної допомоги, які закінчились летально, 2014 р.

\begin{tabular}{|l|c|c|c|}
\hline \multicolumn{1}{|c|}{ Показник } & Дніпропетровська & Вінницька & м. Київ \\
\hline $\begin{array}{l}\text { Кількість виїздів бригад екстреної (швидкої) } \\
\text { медичної допомоги, що закінчились летально }\end{array}$ & 12374 & 4911 & 6265 \\
\hline з них смерть до приїзду, абс. число/\% & $11510 / 93,0 \%$ & $4645 / 94,6 \%$ & $5450 / 87,0 \%$ \\
\hline $\begin{array}{l}\text { смерть у присутності бригад екстреної } \\
\text { (швидкої) медичної допомоги, абс. число/\% }\end{array}$ & $864 / 7,0 \%$ & $266 / 5,4 \%$ & $815 / 13,0 \%$ \\
\hline
\end{tabular}

Таблиця 14. Дані щодо чисельності автомобілів екстреної медичної допомоги та їх оснащення навігаційним та радіозв'язком, 2014 р.

\begin{tabular}{|l|c|c|c|}
\hline \multicolumn{1}{|c|}{ Показник } & Дніпропетровська & Вінницька & м. Київ \\
\hline $\begin{array}{l}\text { Чисельність автомобілів екстреної (швидкої) } \\
\text { медичної допомоги }\end{array}$ & 340 & 205 & 187 \\
\hline $\begin{array}{l}\text { Кількість автомобілів, забезпечених } \\
\text { радіозв'язком та навігаційними приладами }\end{array}$ & $275 / 80,8$ & $45 / 22,0 \%$ & $187 / 100$ \\
\hline
\end{tabular}


Таблиця 15. Окремі показники ефективності та якості медичної допомоги, 2014 р.

\begin{tabular}{|l|c|c|c|}
\hline \multicolumn{1}{|c|}{ Показник } & Дніпропетровська & Вінницька & м. Київ \\
\hline $\begin{array}{l}\text { Кількість прикріпленого населення на одного лікаря, } \\
\text { який надає ПМД (дільничного терапевта, дільничного } \\
\text { педіатра, лікаря загальної практики-сімейного лікаря) }\end{array}$ & 2072 & 1785 & 2009 \\
\hline $\begin{array}{l}\text { Питома вага хворих із занедбаними формами злоякісних } \\
\text { новоутворень серед усіх хворих з візуальними формами } \\
\text { злоякісного новоутворення, взятих на облік у звітному } \\
\text { році з вперше встановленим діагнозом }\end{array}$ & 17,1 & 5,3 & 12,9 \\
\hline $\begin{array}{l}\text { Питома вага хворих на занедбані форми (фіброзно- } \\
\text { кавернозний) туберкульозу серед усіх форм } \\
\text { туберкульозу легень }\end{array}$ & 1,1 & 0,5 & 0,18 \\
\hline $\begin{array}{l}\text { Кількість проведених оперативних втручань у } \\
\text { стаціонарах на 10 тис. населення по області }\end{array}$ & 593,2 & 564,3 & 560,1 \\
\hline $\begin{array}{l}\text { Кількість проведених оперативних втручань у } \\
\text { стаціонарах, при наданні термінової хірургічної } \\
\text { допомоги на 10 тис. населення по області }\end{array}$ & 30,2 & 27,9 & 38,0 \\
\hline
\end{tabular}

\section{Висновки}

Таким чином, проведений порівняльний аналіз засвідчив створення у пілотних регіонах на базі існуючої мережі закладів охорони здоров'я структурованої за видами медичної допомоги системи медичного обслуговування шляхом відокремлення (або об'єднання) закладів охорони здоров'я, які задовольняють потреби населення у первинній, вторинній та екстреній медичній допомозі. Організоване та забезпечене функціонування у пілотних регіонах центрів первинної медичної (медико-санітарної) допомоги для задоволення потреб населення у такій медичній допомозі. Здійснюється перепрофілювання закладів охорони здоров'я пілотних регіонів, що надають вторинну (спеціалізовану) медичну допомогу, з урахуванням інтенсивності їі надання, а також створення центрів екстреної медичної допомоги. Організована діяльність госпітальних округів, які забезпечують умови для надання населенню вторинної (спеціалізованої) медичної допомоги. Проводиться перерозподіл ресурсів між закладами охорони здоров'я, що надають первинну, вторинну (спеціалізовану) та екстрену медичну допомогу на території зазначених регіонів.

Перспективи подальших досліджень. Державна політика у реформуванні вітчизняної охорони здоров'я має бути спрямована на формування моделі, що найбільш відповідає соціальноекономічним реаліям України. При цьому головним завданням є створення механізмів підвищення рівня медичного обслуговування населення, розширення можливості щодо його доступності та якості. Необхідно запровадити набутий у пілотних регіонах досвід реформування системи охорони здоров'я на національному рівні. Результатом цього неминуче мають бути якісні, позитивні зміни не тільки функцій, але й структури системи охорони здоров'я в цілому, а отже оптимізація їі кадрового потенціалу.

\section{Список літератури}

1. Про порядок проведення реформування системи охорони здоров'я у Вінницькій, Дніпропетровській, Донецькій областях та місті Києві : Закон України № 3612 від 7 липня 2011 року [Електронний документ]. - Режим доступу: http://zakon2.rada.gov.ua/laws/show/3612-17 - Назва з екрану.

2. Про удосконалення моніторингу реформи системи охорони здоров'я : наказ МОЗ України № 494 від 11.06.2013 р. [Електронний документ]. - Режим доступу: www.moz.gov.ua/ua/portal/dn_20130611_0494.html - Назва з екрану.

3. Шевченко М. В. Результати оптимізації вторинної (спеціалізованої) медичної допомоги у пілотних регіонах у 2012 р. / М. В. Шевченко, Ю. Б. Ященко // Східноєвроп. журн. громад. здоров'я. - 2013. - № 1 (21). C. $288-289$.

4. Шевченко М. В. Результати ходу реформування первинної ланки надання медичної допомоги населенню у пілотних регіонах / М.В.Шевченко, Ю. Б. Ященко // Східноєвроп. журн. громад. здоров'я. - 2013. - № 1 (21). - С. 289-290.

5. Шевченко М. В. Стан реформування екстреної медичної допомоги у пілотних регіонах у 2012 р. / М. В. Шевченко, Ю. Б. Ященко // Східноєвроп. журн. громад. здоров'я. - 2013. - № 1 (21). - С. 291. 
СРАВНИТЕЛЬНЫЙ АНАЛИЗ СОСТОЯНИЯ РЕФОРМИРОВАНИЯ СИСТЕМЫ ЗДРАВООХРАНЕНИЯ В ПИЛОТНЫХ РЕГИОНАХ УКРАИНЫ

А.Н. Дзюба, Н.Т. Кучеренко, Л.А. Карамзина

ГУ "Украинский институт стратегических исследований МЗ Украины", г. Киев

Цель: проведение сравнительного анализа внедрения новых организационно-правовых и финансовоэкономических механизмов в пилотных регионах (Винницкая, Днепропетровская области, г. Киев).

Материалы и методы. Были использованы статистические данные пилотных регионов; применялись экономический, статистический, методы сравнительного анализа.

Результаты. В пилотных регионах внедрены новые подходы к организации работы учреждений здравоохранения и их кадрового обеспечения: на базе существующей сети учреждений создана структурированная по видам медицинской помощи система медицинского обслуживания; организована работа центров первичной медицинской помощи; перепрофилированы учреждения здравоохранения, оказывающие вторичную (специализированную) медицинскую помощь, с учетом интенсивности ее оказания; созданы центры экстренной медицинской помощи; оптимизировано кадровое обеспечение.

Выводы. Необходимо внедрить полученный в пилотных регионах опыт реформирования системы здравоохранения на национальном уровне.

КЛЮЧЕВЫЕ СЛОВА: пилотные регионы, первичная медицинская помощь, экстренная медицинская помощь, вторичная медицинская помощь, эффективность, качество медицинской помощи.

\section{THE COMPARATIVE ANALYSIS OF HEALTH CARE SYSTEM REFORMING IN PILOT REGIONS OF UKRAINE}

O.M. Dziuba, N.T. Kucherenko, L.A. Karamzina

PE "Ukrainian Institute of Strategic Researches MHC of Ukraine", Kyiv

Purpose. Carrying out of the comparative analysis of implementation of the new organizational, legal, financial and economic mechanisms in pilot regions (Vinnytsia, Dnipropetrovsk region, Kyiv).

Materials and methods. The statistical data of pilot regions have been used; comparative analysis, economic, statistical methods are applied.

Results In pilot regions new approaches to the organization of work of establishments of public health services and their personnel maintenance are introduced: on the basis of existing network of facilities are created structured on kinds of health care system; work of primary medical aid centers has been organized; redesigned health care facilities, giving the secondary (specialized) medical aid, taking into account the intensity of its provision; the centers of emergency medical care are created; their staffing are optimized.

Conclusions. It is necessary to distribute the experience of health care system reforming got in pilot regions to the national level.

KEY WORDS: pilot regions, primary health care, emergency medical care, secondary health care, efficiency, quality of care.

Рукопис надійшов до редакції 20.03.2015 р.

Відомості про авторів:

Дзюба Олександр Миколайович - д.мед.н., проф., заступник директора з наукової роботи ДУ "Український інститут стратегічних досліджень МОЗ України"; тел. служб.: +38(044) 576-41-49.

Кучеренко Наталія Тимофіївна - к.е.н., завідувач відділу економічних досліджень охорони здоров'я та медичного страхування Ду "Український інститут стратегічних досліджень МОЗ України"; тел. служб.: +38(044) 576-41-19.

Карамзіна Людмила Антонівна - д.б.н., вчений секретар ду "Український інститут стратегічних досліджень МОЗ України"; тел. служб.: +38(044) 576-41-49. 